\title{
Inferior alveolar nerve injury with laryngeal mask airway: a case report
}

Deepak Hanumanthaiah ${ }^{1}$ and Anil Ranganath ${ }^{2^{*}}$

\section{Correction}

Following the publication of our article [1] it was brought to our attention that we inadvertently used the registered trademark of the Laryngeal Mask Company Limited (LMA) as the abbreviation for laryngeal mask airway. A Portex ${ }^{\circledR}$ Soft Seal ${ }^{\circledR}$ Laryngeal Mask was used and not a device manufactured by the Laryngeal Mask Company.

All abbreviations for laryngeal mask airway written as LMA should be written in full as laryngeal mask airway.

\section{Acknowledgements}

Dr Sarmud Masud was a co-author on our article [1]. We have tried to contact Dr Sarmad Masud regarding the publication of this correction article, but have been unsuccessful. We no reason to believe that Dr Sarmad Masud would object to this publication.

\section{Author details}

'Department of Anaesthesia, Cork University Hospital, Cork, Ireland.

2Department of Anaesthesia, Our Lady of Lourdes Hospital, Drogheda, Ireland.

Received: 21 November 2011 Accepted: 30 November 2011

Published: 30 November 2011

\section{Reference}

1. Hanumanthaiah $D$, Masud $S$, Ranganath $A$ : Inferior alveolar nerve injury with laryngeal mask airway: a case report. Journal of Medical Case Reports 2011, 5:122.

\footnotetext{
* Correspondence: dranil_2@rediffmail.com

${ }^{2}$ Department of Anaesthesia, Our Lady of Lourdes Hospital, Drogheda, Ireland

Full list of author information is available at the end of the article
}

Submit your next manuscript to BioMed Central and take full advantage of:

- Convenient online submission

- Thorough peer review

- No space constraints or color figure charges

- Immediate publication on acceptance

- Inclusion in PubMed, CAS, Scopus and Google Scholar

- Research which is freely available for redistribution
C Biomed Central

\section{Biomed Central}

